Regular Research Article

\title{
Monitoring Changes in Coastal Mangrove Extents Using Multi-Temporal Satellite Data in Selected Communes, Hai Phong City, Vietnam
}

\author{
Hai-Hoa Nguyen ${ }^{1, *}$, Lan Thi Ngoc Tran ${ }^{1}$, An Thanh Le ${ }^{1}$, Nghia Huu Nghia ${ }^{1}$, Linh Vo Khanh Duong ${ }^{1}$, Hien Thi \\ Thu Nguyen², Simone Bohm³ ${ }^{3}$ Charles Finny Sathya Premnath ${ }^{4}$ \\ 1 Vietnam National University of Forestry, Vietnam \\ 2 Thai Nguyen University of Agriculture and Forestry, Vietnam \\ 3 University of Hohenheim, Germany \\ 4 Karunya University, India \\ * Correspondence author: hoanh@vnuf.edu.vn
}

\begin{abstract}
Mangrove forests are important and known as one of the most productive ecosystems in the tropics. They reduce the impacts of extreme events, provide important breeding grounds for aquatic species and build the resilience of ecosystem-dependent coastal communities. On the contrary, they are also known as one of the most threatened and vulnerable ecosystems worldwide, which have experienced a dramatic decline due to extensive coastal development during the last half-century. Remote sensing techniques have demonstrated a high potential to detect, identify, map, and monitor mangrove conditions and its changes, which is reflected by a large number of scientific papers published on this topic. The aim of this study was to investigate the multi-decadal changes of mangrove forests selected communes in Hai Phong city, North Vietnam, based on using Landsat and Sentinel 2 data from 2000 to 2018 . The study used these continuous steps: 1) data pre-processing; 2) image classification using Normalized Difference Vegetation Index; 3) accuracy assessments; and 4) multi-temporal change detection and spatial analysis of mangrove forests. The classification maps in comparison with the ground reference data showed the satisfactory agreement with the overall accuracy was higher than $80.0 \%$. From 2000 to 2018, the areas of mangrove forests in the study regions increased by 584.2 ha in Dai Hop and Bang La communes (Region 1) and by 124.2 ha in Tan Thanh, Ngoc Xuyen and Ngoc Hai communes (Region 2), mainly due to the boom of mangrove planting projects and good mangrove management at the local community level.
\end{abstract}

Keywords: GIS; Hai Phong; mangrove dynamics; multi-temporal images; remote sensing

\section{Introduction}

Mangrove forests have distributed in inter-tidal zones where oceans, freshwater, and land merge together (Giri et al., 2011; Hogarth, 2015). They are among the most productive and complex ecosystems on the planet, growing under environmental conditions that extremely are different from others (Hong and San, 1993; Woodroff et al., 2016). Furthermore, mangrove forests are rich in biodiversity, providing a habitat for wide varieties of animal and plant species, so they are considered as a nursery of coastal areas by forming a unique intertidal forests at muddy, loose and wet soils and represented on all continents near the shore belonging tropical and sub-tropical areas (Primavera, 1998; Field et al., 1998; Kuenzer et al., 2011; Asokan, 2012). This structure creates an intricate network of habitat for numerous amphibious and marine animals (Field et al., 1998). Importantly, networks of these sediment-trapping forests buffer the coastline against wave-induced erosion and provide coastal ecosystems and coastal communities a vital line of defence against strong, tropical storms. Moreover, the dual services of coastal protection and habitat for commercially important species make mangrove forests one of the most valuable ecosystems in the world. Unfortunately, like many coastal and marine ecosystems, they are being lost at an extremely rapid rate (Spalding, 2010; Romañach et al, 2018). Clear-cutting for coastal development projects (including construction of shrimp farms, hotels and other infrastructure developments), harvesting for wood, and pollution threatens mangrove forests. Scientists estimate that at least one-third of all mangrove forests has been lost during the last few decades (Thomas et al., 2017; Romañach et al., 
2018). Without active policies that aim to reverse the negative trend and preserve this system, mangrove forests (the valuable services that they provide) may disappear in some areas. In addition, mangrove forests are known as one of the most vulnerable ecosystems worldwide, which have experienced a dramatic decline due to extensive coastal development during the last half-century (Kuenzer etal., 2011; Godoy and Lacerda, 2015). Mangrove forests are also sensitive and fragile related to the change in climate and sea level (Gilman et al., 2008; Alongi, 2015). This is because of the pattern of warm and cold ocean currents. Indeed local anomalies of currents and temperature and furthermore the local evolution can create local changes. A disappearance would represent both an ecological and an economic loss in coastal areas that people cannot afford.

Vietnam with its $3,260 \mathrm{~km}$ of coastline spreads across seven different climatic zones, which provides appropriate conditions for mangrove development. During the 1990s, mangrove loss has been experienced due to the development of shrimp farming both in Vietnam in general and particular in Hai Phong (Hong and San, 1993; Jhaveri et al., 2017). At that time, the Government of Vietnam had a policy of encouraging shrimp farming for export and it then started to be a widespread activity in Vietnam (Van et al., 2017). However, in response to the mangrove loss in Vietnam, consistent work has been piloted to plant and protect mangrove forests by mass organizations, such as the Vietnamese Red Cross and Women's Union, significantly contributing to the recovery of mangrove forests (Hai-Hoa et al., 2013). Today, the Government of Vietnam recognises the importance of mangrove forests and other coastal forests, including promoting adaptation, mitigation, and resilience in the face of climate change by reducing flooding, stabilising coastlines, securing a range of coastal livelihood options, sustaining ecosystem services, increasing biodiversity conservation, and supporting carbon sequestration. In response, the Government of Vietnam has recently been developing new laws and policies, such as Forest law in 2017, the Law on Marine and Island Resources and Environment (LMIRE) in 2015 and the Coastal Forests (CF) (The Vietnam Government, 2016a, 2016b; Jhaveri et al., 2017).

Remote sensing technology is one of those accomplishments of aerospace science that are applied widely in many economic sectors around the world (Satyanarayana et al., 2018). The potential use of remote sensing technology and GIS has helped scientists and major planners have alternative options of strategies in management of talent natural resources and environment (Hu et al., 2018). As a result, remote sensing and GIS are used as an effective tool in management and control close to the current forest resources (Giri, 2016; Cissell et al., 2018). To strengthen the management of land use, the identification area and purpose of land use are significant, including maps of land use and land cover status. Many methods of mapping land use and land cover, including using the threshold values of Normalised Difference Vegetation Index (NDVI) (Bhandari, et al., 2012; Ibrahim, et al., 2013; Taufik et al., 2016; Dalezios, et al., 2017; Hashim et al., 2019) have used GIS technology due to its high efficiency in information processing, easy change detection and continuous update information; and its detailed evaluation of coastal land use changes (Areendran et al., 2013; Mohammad et al., 2017). In Hai Phong City, coastal land use planning is a key step of the assessment in land use status (The Government of Vietnam, 1998, 2001, 2006, 2017). Although, every year there are reports about mangroves status, most of the owners report based on mapping by traditional rudimentary methods, that is one complicated work, hard work and insistence take a lot of time (Dat and Yoshino, 2011, 2015). Furthermore, the construction of a mangrove forest map requires high accuracy and up-to-date information. Therefore, the application of remote sensing images in combination with the geographic information system to build a map of mangrove forest change will help local authorities to manage coastal mangrove forest effectively and efficiently. This study was performed using these two main points. Firstly, the study evaluated the changes in the areas of mangrove forests over given periods of time by using the threshold values of NDVI. Secondly, the main drivers of changes in mangrove forests were identified as good lessons learnt for better management of mangrove forests. 


\section{Materials and Methods}

\subsection{Study area}

Hai Phong is an essential port city, a centre of industry, service, and tourism in the key economic region of northern Vietnam. Being located between $20^{\circ} 35^{\prime} \mathrm{N} \div 21^{\circ} 01^{\prime} \mathrm{N}$ and $106^{\circ} 29^{\prime} \mathrm{E} \div 107^{\circ} 05^{\prime} \mathrm{E}$, Hai Phong is about $120 \mathrm{~km}$ away from the Hanoi capital and part of the Red River with 5 large estuaries flowing into the sea, including Thai Binh, Van Uc, Lach Tray, Cua Cam and Nam Trieu with $125 \mathrm{~km}$ sea dike long (The Government of Vietnam, 2016b, 2017). Mangrove forests in Hai Phong include zone I, the northeast coastal zone stretching from Ngoc Cape to Do Son cape, and zone II, the Northern plain coastal zone stretching from Do Son cape to Lach Truong cape (Hong and San, 1993). It is forecasted that in the coming period, impacts of climate change, such as sea level rise, salinity intrusion and other coastal extreme weather, is more likely to increase the risks of degrading forest ecosystems and biodiversity resources. An increase in population density and the demand for land for socio-economic development of the city at a rapid pace also may put a higher pressure on forest protection, development and monitoring of forest changes. Therefore, the study was conducted in the combined mangrove forest areas of Dai Hop commune in Kien Thuy district, Ngoc Xuyen, Ngoc Hai, Bang La communes in Do Son district and Tan Thanh commune in Duong Kinh district, Hai Phong City as shown in (Fig. 1).
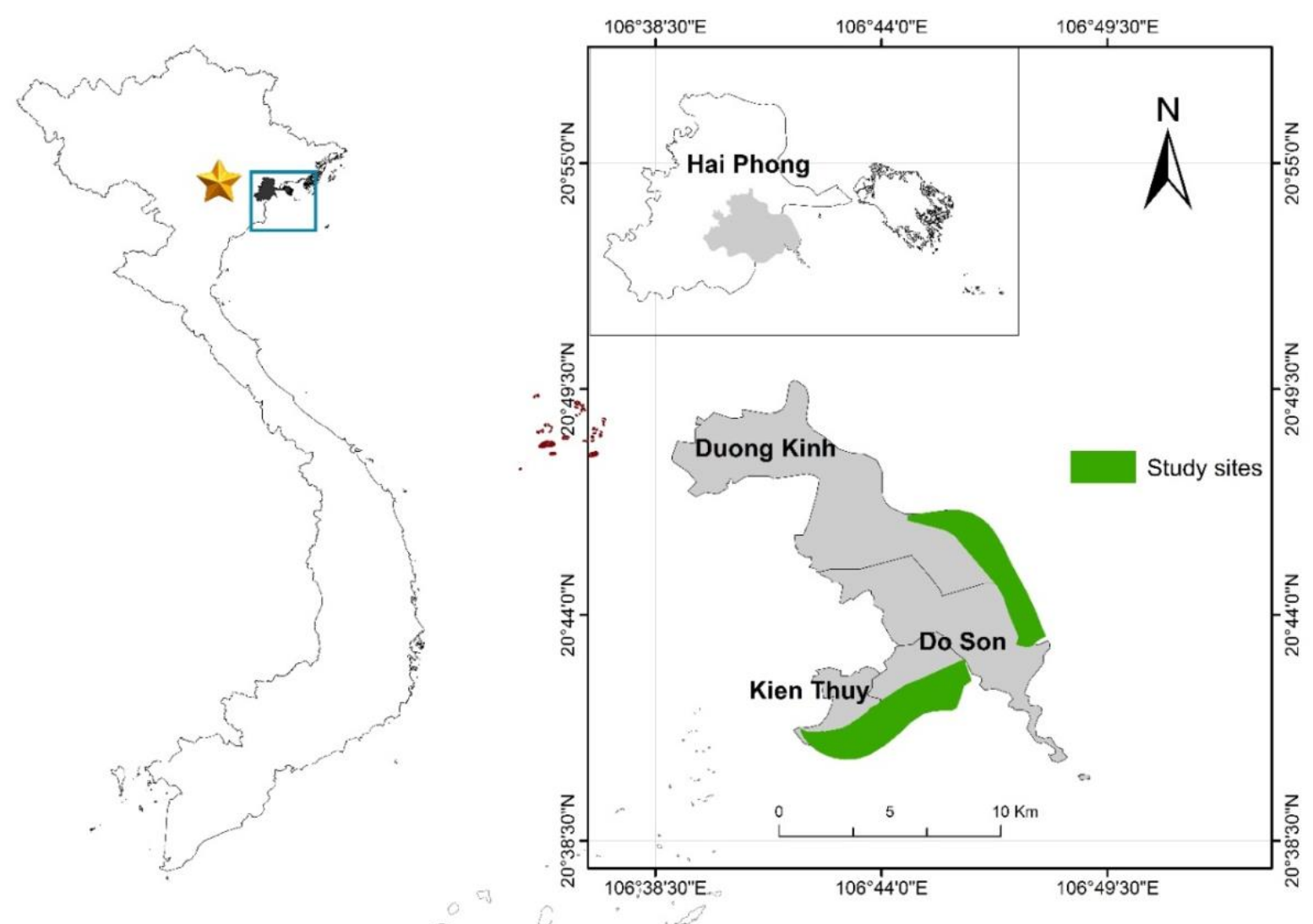

Figure 1. Sampling sites in Hai Phong: (a) Vietnam; (b) Hai Phong City; (c) Study region: Kien Thuy district (Dai Hop commune), Duong Kinh (Tan Thanh commune) and Do Son (Bang La, Ngoc Hai and Ngoc Xuyen communes) districts. 


\subsection{Data collection}

In this study, multiple-temporal satellite images were used to classify mangrove extents in different periods. The used imageries were acquired by several satellite studies, including Landsat 5 and Sentinel 2A shown in Table 01.

Table 1. Remotely sensed data used for detecting changes in mangrove extents.

\begin{tabular}{clccc}
\hline ID & \multicolumn{1}{c}{ Image codes } & Date & Resolution $(\mathrm{m})$ & Path/Row \\
\hline 1 & LT05_L1TP126046_20001105 & $2000 / 11 / 05$ & 30 & $126 / 46$ \\
2 & LT05_L1TP_126046_20060412 & $2006 / 04 / 12$ & 30 & $126 / 46$ \\
3 & LT05_L1TP_126046_20101203 & $2010 / 12 / 03$ & 30 & $126 / 46$ \\
4 & S2A_MSIL1C_20160909T110117b & $2016 / 09 / 09$ & 10 & T48QXH \\
5 & S2A_MSIL1C_20180322T031541 & $2018 / 03 / 22$ & 10 & T48QXH \\
6 & Land cover maps $^{\mathrm{b}}$ & 2005,2010, & $1: 50,000$ & HP DARD \\
& & 2015 & & \\
\hline
\end{tabular}

Source: ahttps://earthexplorer.usgs.gov; ${ }^{b}$ https://scihub.copernicus.eu/dhus; ${ }^{c} H P$ DARD: Hai Phong Department of Agriculture and Rural Development.

This study used secondary data for mangrove management and change analysis, including the availability of remotely sensed data and land cover maps shown as in Table 01 and associated mangrove documents. First, the study has reviewed existing documents from the previous studies, including legal documents (The Government of Vietnam, 2008, 2016a, 2017; Vietnam Law on Forestry, 2017) and other relevant documents (e.g. Hoa and Bao, 2008; Dat and Yoshino, 2013, Anh and Hai-Hoa, 2017) in relation to mangrove management and development in study sites. Besides, to better understand the management status of mangrove forests and their historical changes across the time, the study also conducted the semi-structured interview, with a total of 30 people, including 05 forest rangers, 10 local guards; 10 local people and 05 local authorities from People's Committee at district as well as commune levels. Local people were selected who have been living nearby mangrove forests for a long time, so they understand very well about the past and current mangrove management and changes. In addition, forest rangers and local guards also were interviewed to obtain the additional information of mangrove management and protection issues, the mangrove species and historical distribution change.

\subsection{Data pre-processing}

Sentinel 2A images in 2016 and 2018 (Level 1C) were downloaded from the European Space Agency's Sentinel Scientific Data Hub (Table 01), which were orthorectified and top of atmosphere images. A further process to Level- $2 \mathrm{~A}$ product was applied to obtain bottom-of-atmosphere corrected reflectance image of Sentinel images by using the Semi-Automatic Classification Plugin in QGIS version 3.10.2 (Castillo et al., 2017; Congedo, 2020). Landsat 5 images were download from the United States Geological Survey (Table 01). Atmospheric correction was performed for Landsat 5 images. In particular, digital numbers of images were converted to at-sensor radiance values and the radiance values were then converted to bottom surface reflectance using ArcGIS 10.3 (Hai-Hoa et al., 2013).

Landsat and Sentinel images were already geo-referenced. In order to obtain a pixel-to-pixel match between two images, Sentinel 2A in 2018 and Landsat 5 in 2010 were used to register Sentinel 2016 and Landsat images $(2000,2006)$, respectively. Besides, to improve the quality of image classification, single bands of Sentinel imageries (Bands 2, 3, 4 and 8) and of Landsat imageries (Bands 1, 2, 3, 4 and 5) were combined known as the composite bands in ArcGIS 10.3. These steps were done as the following steps: ArcTool Box $=>$ Data Management Tools $=>$ Raster $=>$ Raster Processing $=>$ Composite Bands.

The mask was created and then used to define the areas of mangrove forests in the pre- 
processed Landsat and Sentinel images (2000, 2006, 2010, 2016 and 2018). These images were clipped to extract only areas where mangrove forests were more likely to be present (e.g. low-lying areas and inter-tidal zones), and to exclude large coastal areas where mangrove forests did not occur (e.g. far inland, highlands and open ocean) before the image classification was undertaken. The clip steps were done as the following steps: ArcTool box $=>$ Data Management Tools $=>$ Raster $=>$ Raster Processing $=>$ Clip.

\subsection{Mangrove classification}

To construct thematic land cover maps, including mangrove forests map, this study mainly used Normalized Difference Vegetation Index (NDVI) in combination with visual interpretation approach. Study determined the threshold values of NDVI for each land cover type (mangrove forests, water bodies and others) and then it was used to construct a thematic land cover map each year with support of the ground reference data.

Normalized Difference Vegetation Index (NDVI): NDVI was calculated as the following formula:

NDVI= (Band NIR-Band RED)/ (BandNIR+BandRED) (Rouse et al., 1973; Green et al., 1998)

Where Band NIR is a near-infrared band, and Band RED is a red band Near-infrared colour with the wavelength from $0.7 \div 1.0 \mu \mathrm{m}$, Red color band with the wavelength from $0.4 \div 0.7 \mu \mathrm{m}$. For Sentinel 2A: Band NIR is Band 8, while Band RED is Band 4 (Mas, 1999). For Landsat 5, Band NIR is Band 4, while Band RED is Band 3.

NDVI used 2 Bands to identify areas with vegetation (mangrove forests) and non-vegetation (non-mangrove forests) classes because it allows an accurate representation and discrimination based on characteristics of chlorophyll in the leaves that absorbs light in the visible spectrum $(0.4 \div$ $0.7 \mu \mathrm{m})$, and reflected the network light on the near-infrared spectral range $(0.7 \div 1.0 \mu \mathrm{m})$ (Green et al., 1998).

This index was first put into use in 1973 by (Rouse et al., 1973). NDVI is widely used for the study of vegetation, such as estimating crop yields, the ability to crop, and convert fields. In addition, NDVI is directly related to parameters, such as surface soil layer, the photosynthesis of plants, water, and biomass calculation (Fensholt et al., 2009). The NDVI values are calculated, ranging from -1.0 to +1.0 , showing the clear distribution of vegetation covers in the study area (e.g. Wang and Tenhunen, 2004; Fensholt et al., 2009). It also represents the different vegetation groups through the values each plant. They are usually divided into levels: from negative value to 0 refers to water; from the values of less than 0.1 usually represents to soil, rock, sand or snow; from the value of approximately 0.2 to 0.5 are bushes, grass or dry fields; from 0.6 to 0.9 or close to 1.0 are trees and plants (Singh, 1989; Tucker et al., 2005). Therefore, NDVI was considered and selected as a useful tool for determining the presence of mangrove forests in the study.

Visual Interpretation: In this study, the visual Interpretation approach referred to use the knowledge and experience to separate the areas of mangrove forests and other classes from remote sensing imageries (Hai-Hoa, 2016). This approach was used to support NDVI to identify NDVI thresholds and classify reference data by using higher spatial resolution Google Earth, Google Maps, etc. (Hu et al., 2013; Malarvizhi et al., 2016).

\subsection{Accuracy assessments}

In this study, a thematic land cover map derived with classification according to NDVI values each selected year was considered and accurate if it gave an unbiased representation of the land covers (Dan et al., 2016). Accuracy assessments were conducted by comparing the classification results with reference data that was thought to reflect accurately true land covers (Dan et al., 2016). To evaluate the accuracies of satellite images classified and assess the accuracies of NDVI approach 
each selected year, users, producer's and overall accuracies with kappa statistics were derived from the error matrix. In particular, kappa values were categorised into different groups where kappa values were less than zero, it then indicated no agreement; from $0 \div 0.20$ referred to a slight agreement; $0.21 \div 0.40$ represented as a fair agreement, from $0.41 \div 0.60$ were considered as a moderate agreement, whereas $0.61 \div 0.80$ were regarded as substantial and $0.81 \div 1.00$ referred to an almost perfect agreement (Conchedda et al., 2008; Dan et a., 2016; Maryantika and Lin, 2017; Thomas et al., 2018). A total of 1140 GPS points collected by GPS map 78s were selected using a stratified random sampling approach, which randomly distributed throughout three classes (mangrove forests, water bodies and others) based on the 2018 map across two regions. From the year of 2018, validation points were collected from the field data survey and the availability of Google Earth, whereas the years of 2006, 2010 and 2016, validation points were collected from Land cover maps provided by the Hai Phong Agriculture and Rural Department (Table 01) and from Google Earth on those years. Unfortunately, the year of 2000 was not available from Land cover map, so validation points were obtained based on taking the social interviews with forest rangers and local people who have been in charge of mangrove management to determine whether mangrove forests existed together with nearly closed year of 2000 from Google Earth.

\subsection{Drivers of mangrove changes and feasible solutions for better mangrove management}

Drivers and solutions were defined based on achieved results for a better management situation to enhance the quality and the quantity of mangrove forests and especially improving local people's livelihoods.

\section{Results and discussions}

\subsection{Assessments of mapping accuracies}

As results of NDVI calculated and analysed, the NDVI threshold for each land cover type was defined. In particular, the NDVI thresholds for mangrove forests, others and water bodies were determined as greater than 0.2 , from less than 0.2 to 0.01 , less than 0.01 , respectively. These threshold values were then used to construct a thematic land cover map each year. These thresholds are also confirmed by other previous studies by Bhandari et al., (2012); Ibrahim et al., (2013); Taufik et al., (2017); Hashim et al., (2019).

In order to assess the reliability of NDVI thresholds selected, this study used 575 and 565 GPS validation points collected from the ground reference data in Region 1 and Region 2, respectively for three classes, including mangrove forests ( 223 validation points in Region 1, 216 validation points in Region 2), water bodies (167 validation points in Region 1, 165 validation point in Region 2), and others (185 validation points in Region 1, 184 validation points in Region 2). These GPS validation points were followed by a stratified random sampling approach by area and were then used to compare with land covers map classified in 2000, 2006, 2010, 2016 and 2018 based on NDVI thresholds. The comparison results indicated that most images classified generally had the levels of averaged producer's and user's accuracies quite high across all studied years (>80.0\%). Specifically, the overall map accuracies in Region 1 (Dai Hop and Bang La communes) and Region 2 (Tan Thanh, Ngoc Xuyen and Ngoc Hai communes) were respectively $86.4 \%$ and $83.7 \%$ for $2000 ; 82.3 \%$ and $87.5 \%$ for $2006 ; 85.2 \%$ and $91.5 \%$ for $2010 ; 85.0 \%$ and $79.5 \%$ for $2016 ; 85.6 \%$ and $84.0 \%$ for 2018 (Table 02). In addition, kappa coefficients were greater than 0.7 in both Regions (Table 2), showing that there was a substantial agreement between the classification results and reference data (Dan et al., 2016; Maryantika and Lin, 2017; Thomas et al., 2018). During accuracy assessments, mapping accuracies might be affected by several possible factors, including mixed-pixel issues, images taken at different time, tidal regime and cloud cover percentage. In short, the results confirmed the effectiveness of using remotely sensed data of Landsat and Sentinel for monitoring the spatio- 
temporal distributions of mangrove forests in the study regions for five particular years of 2000, 2006, 2010, 2016, and 2018.

Table 2. Accuracy assessments using NDVI method in study sites.

\begin{tabular}{|c|c|c|c|c|c|c|c|c|}
\hline & \multicolumn{4}{|c|}{ Region 1 } & \multicolumn{4}{c|}{ Region 2 } \\
\hline Assessments & $\begin{array}{c}\text { Averaged } \\
\text { producer } \\
\text { accuracy (\%) }\end{array}$ & $\begin{array}{c}\text { Averaged } \\
\text { user } \\
\text { accuracy } \\
(\%)\end{array}$ & $\begin{array}{c}\text { Overall } \\
\text { accuracy } \\
(\%)\end{array}$ & $\begin{array}{c}\text { Kappa } \\
\text { coefficient }\end{array}$ & $\begin{array}{c}\text { Averaged } \\
\text { producer } \\
\text { accuracy (\%) }\end{array}$ & $\begin{array}{c}\text { Averaged } \\
\text { user } \\
\text { accuracy (\%) }\end{array}$ & $\begin{array}{c}\text { Overall } \\
\text { accuracy } \\
\text { (\%) }\end{array}$ & $\begin{array}{c}\text { Kappa } \\
\text { coefficient }\end{array}$ \\
\hline 2000 & 86.0 & 86.2 & 86.4 & 0.80 & 85.0 & 85.1 & 83.7 & 0.78 \\
\hline 2006 & 82.0 & 82.2 & 82.3 & 0.73 & 88.8 & 89.0 & 87.5 & 0.83 \\
\hline 2016 & 85.0 & 84.8 & 85.2 & 0.78 & 92.9 & 93.0 & 91.5 & 0.90 \\
\hline 2018 & 84.7 & 85.0 & 85.0 & 0.77 & 80.6 & 80.7 & 79.5 & 0.71 \\
\hline
\end{tabular}

Note: Region 1: Dai Hop and Bang La communes; Region 2: Tan Thanh, Ngoc Xuyen and Ngoc Hai communes.

\subsection{Key drivers in the extents of mangrove forests}

Multi-temporal changes in the extent of mangrove forests in the study regions among different periods, including 2000-2006, 2006-2010, 2010-2016, 2016-2018, and 2000-2018, were detailed in Table 3.

Table 3: Land use and cover changes across different periods in the study regions.

\begin{tabular}{|c|c|c|c|c|c|c|c|c|c|c|c|c|}
\hline \multirow{3}{*}{ Periods } & \multicolumn{6}{|c|}{ Region 1} & \multicolumn{6}{|c|}{ Region 2} \\
\hline & \multicolumn{2}{|c|}{ Mangroves } & \multicolumn{2}{|c|}{ Water bodies } & \multicolumn{2}{|c|}{ Others } & \multicolumn{2}{|c|}{ Mangroves } & \multicolumn{2}{|c|}{ Water bodies } & \multicolumn{2}{|c|}{ Others } \\
\hline & $\mathrm{Ha}$ & $\%$ & $\mathrm{Ha}$ & $\%$ & $\mathrm{Ha}$ & $\%$ & $\mathrm{Ha}$ & $\%$ & $\mathrm{Ha}$ & $\%$ & $\mathrm{Ha}$ & $\%$ \\
\hline 2000 & 87.5 & & 965.5 & & 66.7 & & 49.5 & & 777.1 & & 54.7 & \\
\hline 2006 & 337.7 & & 570.6 & & 211.4 & & 68.9 & & 623.0 & & 189.4 & \\
\hline $2000-2006$ & 250.2 & 285.9 & -394.9 & -40.9 & 144.7 & 216.9 & 19.4 & 39.2 & -154.1 & -19.8 & 134.7 & 246.3 \\
\hline 2010 & 426.2 & & 569.4 & & 124.1 & & 116.5 & & 526.2 & & 238.6 & \\
\hline 2006-2010 & 88.5 & 26.2 & -1.2 & -0.2 & -87.3 & -41.3 & 47.6 & 69.1 & -96.8 & -15.5 & 49.2 & 26.0 \\
\hline 2016 & 513.1 & & 570.1 & & 36.6 & & 180.4 & & 684.4 & & 16.4 & \\
\hline 2010-2016 & 86.9 & 20.4 & 0.7 & 0.1 & -87.5 & -70.5 & 63.9 & 54.8 & 158.2 & 30.1 & -222.2 & -93.1 \\
\hline 2018 & 671.7 & & 222.8 & & 222.2 & & 173.7 & & 547.0 & & 163.6 & \\
\hline $2016-2018$ & 158.6 & 30.9 & -347.3 & -60.9 & 185.6 & 507.1 & -6.7 & -3.7 & -137.4 & -20.1 & 147.2 & 897.6 \\
\hline 2000- 2018 & 584.2 & 667.7 & -742.7 & -76.9 & 155.5 & 233.1 & 124.2 & 250.9 & -230.1 & -29.6 & 108.9 & 199.1 \\
\hline
\end{tabular}

Note: Region 1: Dai Hop and Bang La communes; Region 2: Tan Thanh, Ngoc Xuyen and Ngoc Hai communes.

As shown in Table 03, the overall areas of mangrove forests increased significantly over the period of 2000-2018, experiencing in both study Region 1 (Bang La and Dai Hop communes) and Region 2 (Tan Thanh, Ngoc Xuyen and Ngoc Hai communes) with 584.2 ha and 124.2 ha, respectively (equivalent to $35.1 \%$ year $^{-1}$ in Region 1 and $13.2 \%$ year $^{-1}$ in Region 2). Similarly, the areas of others' class, including bare soil, settlements, mudflats, beaches and non-mangrove plants, also increased during the same period with $12.3 \%$ year $^{-1}$ and $10.5 \%$ year $^{-1}$ in Region 1 and Region 2, respectively. However, the areas of water bodies were observed to decline by $4.0 \%$ year $^{-1}$ in Region 1 and $1.6 \%$ year $^{-1}$ in Region 2 during the period of 2000- 2018. Surprisingly, the areas of mangrove forests slightly declined by 6.7 ha (3.7\%) from 2016- 2018 in Region 2, while mangrove forests continued to increase by 158.6 ha (equivalent to $30.9 \%$ ) in Region 1. It was also seen that water bodies decreased in all periods, except for the period of 2010- 2016 with $0.1 \%$ and $30.1 \%$ in Region 1 and Region 2, respectively. This decrease could be explained by the water level variations known as the low and high tide regimes in two images collected for comparison (Zhang et al., 2017; Laengner et 
al., 2019) and temporal differences between two images selected (Zhang et al., 2017). In fact, there was a tidally temporal difference between two images captured in 2010 and 2016 in this study. As tide came in the study areas, some areas belonged to others class, including mudflats and bare soil, were covered by water, thus narrowing its areas and vice versa (Table 03).

\section{Drivers of changes in mangrove forests:}

As results of changes in land use and land cover analysis from remote sensing data and social interviews, the study delineated key drivers that caused mangrove forests dynamics in each period as the following:

Period of 2000-2006: This period was evidenced with the international involvements in mangrove planting projects. Mangrove forests were planted by NGOs, Japanese Red Cross in period of 1997-2005 and Action for Mangrove Reforestation in the period of 1994- 2005 (Report Breaking the waves-Impact analysis of coastal afforestation for disaster risk reduction in Viet Nam, 2011). In particular, under these financial supports of the Japanese Red Cross and Vietnamese Red Cross Society, planting of mangrove forests was not carried out in Hai Phong and but also implemented in all Northern provinces to increase the resilience of communities to natural disasters. These projects were signed with individual agreements of households who participated in planting or protecting mangrove forests. The provincial Red Cross chapter made direct payments to local households.

In 2005, as the typhoons hit the study regions, all shrimp farms were seriously damaged and many shrimp farmers fell deeply in debt (Dat and Yoshino, 2013). Surprisingly, there was either no damage or lesser damage of the shrimp farms where dense mangrove forested areas were existing. On the contrary, previously existing mangrove areas that were converted to shrimp aquaculture by local people were devastated by the typhoons (Dat and Yoshino, 2013). Since after 2005, people realised the important roles of mangrove forests in protecting the dike system and their livelihoods against the typhoons. The planting mangrove forests in vulnerable areas and previously existing mangroves then received more active local participation. Consequently, mangrove forests have been seen a rapid development all thanks to active local participation in mangrove forest management in close cooperation with local authorities (Dat and Yoshino, 2013).

Period of 2006-2010: This period was experienced with an increase of mangrove forests both in Region 1 (Bang La and Dai Hop communes) and Region 2 (Tan Thanh, Ngoc Xuyen and Ngoc Hai communes) with 88.1 ha and 47.6 ha, respectively. During this period, apart from mangrove planting projects funded by the Japanese Red Cross and other NGOs, the national plan for mangrove restoration and development for 2008- 2015 was approved by the Prime Minister of Vietnam, with a goal of increasing the areas of national mangrove forests from 209,741 ha to 307,295 ha (The Government of Vietnam, MARD, 2008). Such increase was expected mainly from the mangrove planting projects covering 29 coastal provinces. Forest contracting and allocation to local households and communities were implemented during this period (The Government of Vietnam, MARD, 2008).

Period of 2010-2016: This period was also experienced with an increase of mangrove forests by 86.9 ha and 43.9 ha in Region 1 and Region 2, respectively. In 2012, the National Strategy for Environmental Protection until 2020 and Vision until 2020 was set a goal of increasing overall forest cover $43.0 \%$ by 2010 , while improving forest quality and restoring mangrove forests (Hawkins et al., 2010). The master plan on development of the fisheries sector until 2020 and vision through 2020 had a goal of promoting sustainable extraction of aquatic products and sustainable aquaculture development across 1.4- 1.5 million ha of surface water and production centres in the Red River Delta (Hawkins et al., 2010).

Period of 2016- 2018: This period was witnessed an increase of mangrove forests in Region 1 with 158.6 ha, while a reduction of mangrove forests was recorded in Region 2 with 6.7 ha of mangrove loss. This could be explained due to many storms landed on Hai Phong coast during this period. In 2017, there was a total of 20 storms and tropical depressions recorded in Hai Phong coast 
(OECD, 2018). In particular, mangrove areas slightly decreased in Duong Kinh and Do Son districts. During this period, policy on coastal forest management, protection, rehabilitation and development in response to climate change were also launched (The Government of Vietnam, 2016a; 2016b).

Overall, this study proved that mangrove forests were significantly increased during 2000- 2018 due to good management at the community level and a number of projects and decrees that were launched effectively. The extents of mangrove forests fluctuated due to mangrove plantation and development projects as well as thanks to the local participation in mangrove management for long periods. From interviewing local authorities and local people in combination with findings from remote sensing analysis, study found that mangrove forests were not much influenced by agricultural or aquaculture activities during the study period. This is because local people have constructed shrimp ponds or cultivated crops from dikes back, while mangrove forests distribute the outermost. The study of Dat and Yoshino (2015) were conducted in the whole of Hai Phong coast during the period of 1989-2013. The findings show that mangrove forests were experienced with an increase by 636 ha and 355 ha during the period of 2001- 2013 and 1989- 2013 over Hai Phong coast. Similarly, this study recorded a significant increase of mangrove areas by 584.2 ha and 124.2 ha in Region 1 and Region 2 during the period of 2000- 2018 as shown in Figure 02. However, there is a variation of mangrove extents between two studies due to the different scope of study. The study by Dat and Yoshino (2015) was conducted in the whole of Hai Phong coast, whereas this study was carried out in some parts of Hai Phong coast. However, both study have all confirmed that mangrove forests increased during the same period of study.
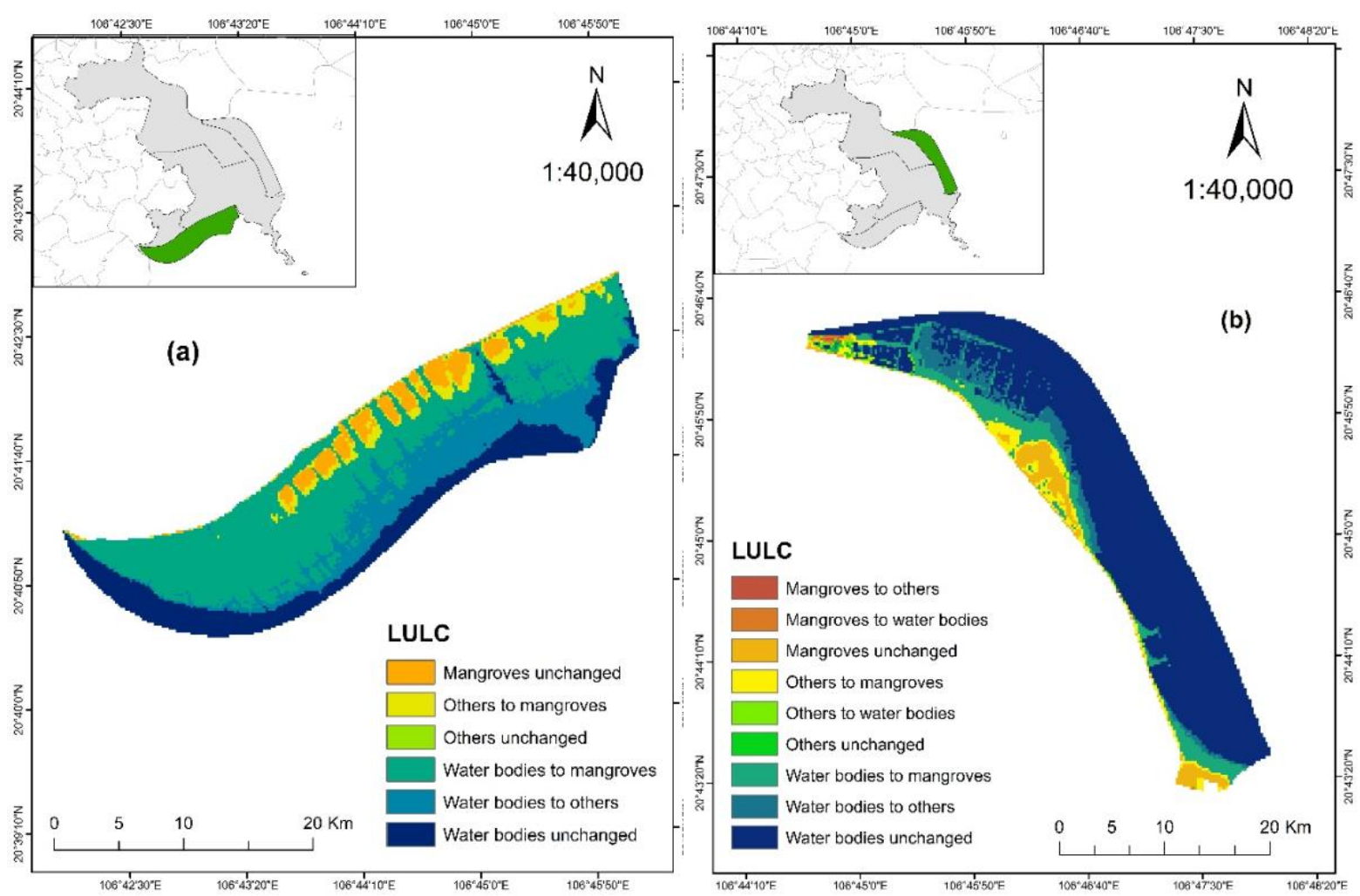

Figure 2: Mangrove forest extents in (a) Dai Hop commune in Kien Thuy district and Bang La commune in Do Son district and (b) Tan Thanh commune in Duong Kinh district; Ngoc Xuyen and Ngoc Hai communes in Do Son district during 2000-2018. Mangrove forests include mature mangrove forests and young mangroves; Water bodies include aquaculture and sea water; others consist of wetlands and other plants. 
These figures showed that changed classes in Dai Hop (Kien Thuy district) and Bang La (Do Son district) communes were 3 classes (Fig. 2a), while in Tan Thanh (Duong Kinh district), Ngoc Xuyen and Ngoc Hai (Do Son district) communes were 6 classes (Fig. 2b). In particular, in Dai Hop and Bang La communes, main drivers of an increase of mangrove forests were due to mangrove plantation from the areas covered by water bodies and others. This is because there were mangrove rehabilitation programs that were conducted successfully on account of community-based mangrove management in closed cooperation with local authorities (Dat and Yoshino, 2013). In contrast to Dai Hop and Bang La communes, both an increase of mangrove forests and mangrove loss were recorded in Tan Thanh, Ngoc Xuyen and Ngoc Hai communes. Mangrove forests were converted into water bodies (expansion of shrimp aquaculture) and others (Dat and Yoshino, 2013).

\subsection{Lessons learnt for better mangrove management in Hai Phong city}

In this study, mangrove forests have been both recorded the increases and decreases during the period of 2000- 2018 in Hai Phong city. Apart from a good lesson learnt from Dai Hop and Bang La communes (Region 1) in terms of the effective community-based mangrove management in cooperation with local authorities and mangrove management mechanism for Tan Thanh, Ngoc Xuyen and Ngoc Hai communes (Region 2) in particular, there are also good models of mangrove forests management in Indonesia and Thailand that should be taken into consideration in Hai Phong coast in general.

A number of studies shows that the Government of Thailand has put strong efforts to control mangrove deforestation and promote community-based management of remaining mangrove forests; replant mangrove forests and mitigate some worst impacts on coastal villages by developing institutions to support local community management (Thampanya et al., 2006; Kongkeaw et al., 2019). The factors leading to success in community-based mangrove management have been also clearly defined, including leadership, livelihood and occupational change, experience and capacity to organise into groups, NGO support in initial phases, increasing government support and recognition in subsequent phases (Chu 2006; Kongkeaw et al., 2019). In fact, some factors have been already existed in a successful model of mangrove management in Dai Hop and Bang La communes, whereas they have been almost absent in Tan Thanh, Ngoc Xuyen and Ngoc Hai communes. Therefore, these factors should be taken into account in Hai Phong coast as model of communitybased mangrove forests in Hai Phong is facilitated.

In addition, similar to Thailand, community-based mangrove management is also enhanced through eco-tourism development in Indonesia (Yilmaz et al., 2013; Basyuni et al., 2018). It claims that mangrove ecotourism is a kind of sustainable land use, which contribute to environmental protection, accommodate socio-economic benefits to the local community via indirect values of the natural resources (Datta et al., 2012; Richards and Friess, 2012; Yilmaz et al., 2013; Basyuni et al., 2018). Furthermore, active community participation in mangrove forest management is required by taking 2 major factors into consideration (Armitage, 2002, Hanifah et al., 2018), including management factors (namely, local participation in mangrove forest management; decision making process; local involvements in planning, implementing and monitoring in managing mangrove forests; institutional and administrative community participation; communities considered as managers, implementers and processors in mangrove forests management), knowledge factors (community education levels; benefits of mangrove forests for the community; support provided by the community in mangrove forest management). In some cases, deforested and degraded mangrove areas is more likely to be rehabilitated and restored by selecting potential rehabilitation sites. Delineations of degraded mangrove forests are needed to promote regrowth and enrichment planting (Giri et al., 2008). In Hai Phong, results of local interviews dominantly show that the integration of ecotourism into community-based mangrove management has not been encouraged. Therefore, model of mangrove ecotourism development should be taken into consideration with a 
good samples from Indonesia.

In short, success in community-based mangrove management can not be applied by a single formula that can be lifted from the Thailand and Indonesia cases, but the usefulness of both cases in how define the factors that are more likely to facilitate the success in Hai Phong coast, In particular in Tan Thanh, Ngoc Xuyen and Ngoc Hai communes. However, the key factors contributing to the effectiveness of mangrove management as case studies in Thailand and Indonesia at the community level should be paid attention into implementing the model of community-based mangrove management in Hai Phong city.

\section{Conclusions}

The present study analysed the distribution of mangrove forests and then detected changes in four selected periods, namely 2000-2006, 2006-2010, 2010-2016 and 2016-March 2018. The results indicated that during four periods, mangrove areas have increased over the long periods of time, all thanks to the close cooperation of local people and local authorities in mangrove forest management and protection. The study also highlights the relevant adoption of using remote sensing data to determine the dynamics of mangrove forests by using NDVI approach with accuracies greater than $80.0 \%$ in all selected years. This study has also identified regions and periods of intensive mangrove dynamics that will raise future monitoring in these regions, while pointed out evidence impacting mangrove forests changes. In addition, the study has provided a good reference data for local authorities and policymakers and proposed a variety of possible solutions to plan and manage mangrove resources sustainably and deal with climate change in the study sites. Good lessons for Hai Phong coast, Vietnam that could be adapted from Indonesia and Thailand case studies are development of community-based mangrove management and mangrove ecotourism models.

\section{Acknowledgments}

This research is funded by Vietnam National Foundation for Science and Technology Development (NAFOSTED) under grant number 105.08-2017.05. The authors also would like to thank Commune's Red Cross and Commune People's Committee and local people in Kien Thuy, Do Son and Duong Kinh districts, Hai Phong City for supporting us when collecting data.

\section{Conflicts of interest}

The authors declare no conflict of interest.

\section{References}

Alongi, D. M. (2015). The impact of climate change on mangrove forests. Current Climate Change Reports, 1(1), 30-39. doi: https://doi.org/10.1007/s40641-015-0002-x.

Anh, N. N., \& Hai-Hoa, N. (2017). Evaluating policy effectiveness on coastal mangrove management: case study in Kien Thuy and Do Son districts, Hai Phong city. Journal of Forestry Science and Technology, 2, 43- 54.

Areendran, G., Rao, P., Raj, K., Mazumdar, S., \& Puri, K. (2013). Land use/land cover change dynamics analysis in mining areas of Singrauli district in Madhya Pradesh, India. Tropical Ecology, 54(2), 239-250.

Armitage, D. (2002). Socio-institutional dynamics and the political ecology of mangrove forest conservation in Central Sulawesi, Indonesia. Global Environmental Change, 12(3), 203-217. doi: https://doi.org/10.1016/S0959-3780(02)00023-7.

Asokan, P. K. (2012). Mangroves and its importance to Fisheries. ISO 690.

Bao, T.Q., \& Hoa, L. S. (2018). Using Sentinel satellite image to estimate biomass of mangrove forest 
in Vinh Quang commune, Tien Lang district, Hai Phong city. Journal of Forestry Science and Technology, 5, 71- 79.

Basyuni, M., Bimantara, Y., Siagian, M., Wati, R., Slamet, B., Sulistiyono, N., ... \& Leidonad, R. (2018, March). Developing community-based mangrove management through eco-tourism in North Sumatra, Indonesia. In IOP Conference Series: Earth and Environmental Science (Vol. 126, No. 1, p. 012109). IOP Publishing. doi: https://doi.org/10.1088/1755-1315/126/1/012109

Bhandari, A. K., Kumar, A., \& Singh, G. K. (2012). Feature extraction using Normalised Difference Vegetation Index (NDVI): A case study of Jabalpur city. Procedia Technology, 6, 612- 621.

Castillo, J. A. A., Apan, A. A., Maraseni, T. N., \& Salmo, S. G. (2017). Estimation and mapping of aboveground biomass of mangrove forests and their replacement land uses in the Philippines using Sentinel imagery. ISPRS Journal of Photogrammetry and Remote Sensing, 134, 70-85. https://doi.org/10.1016/j.isprsjprs.2017.10.016

Chu, T. H. (2006). Environment and livelihoods in tropical coastal zones: Managing agriculturefishery-aquaculture conflicts (Vol. 2). CABI.

Cissell, J. R., Delgado, A. M., Sweetman, B. M., \& Steinberg, M. K. (2018). Monitoring mangrove forest dynamics in Campeche, Mexico, using Landsat satellite data. Remote Sensing Applications: Society and Environment, 9, 60-68. doi: https://doi.org/10.1016/j.rsase.2017.12.001.

Conchedda, G., Durieux, L., \& Mayaux, P. (2008). An object-based method for mappng and change analysis in mangrove ecosystem. ISPRS Journal of Photogrammetry and Remote Sensing, 63, 578- 589. doi: https://doi.org/10.1016/j.isprsjprs.2008.04.002

Congedo, L. (2020). Semi-Automatic Classification Plugin documentation. Release 6.4.0.2. 243p.

Dan, T. T., Chen, C. F., Chiang, S. H., \& Ogawa, S. (2016). Mapping and change analysis in mangrove forest by using Landsat imagery. ISPRS Annals of the Photogrammetry, Remote Sensing and Spatial Information Science, 8, 109- 116.

Dalezios, N. R., Gobin, A., Tarquis, A. M., \& Eslamian, S. (2017). Agricultural drought indices: Combining crop, climate and soil factors in Handbook of Drought and Water Scarcity: Principles of Drought and Water Scarcity. CRC Press, Taylor and Francis Group.

Dat, P. T., \& Yoshino, K. (2013). Comparing mangrove forest management in Hai Phong City, Vietnam towards sustainable aquaculture. Procedia Environmental Sciences, 17, 109-118. doi: https://doi.org/10.1016/j.proenv.2013.02.018

Dat, P.T., \& Yoshino, K. (2011). Monitoring mangrove forest using multi-temporal satellite data in the Northern Coast of Vietnam. In the 32nd Asian Conf. on Remote Sensing.

Dat. P.T., \& Yoshino, K. (2015). Mangrove mapping and change detection using multi-temporal Landsat imagery in Hai Phong City, Vietnam. In Int. Symp. on Cartography in Internet and Ubiquitous Environments.

Dat, P. T., \& Yoshino, K. (2016). Impacts of mangrove management systems on mangrove changes in the Northern coast of Vietnam. Tropics, 24, 141- 151.

Datta, D., Chattopadhyay, R. N., \& Guha, P. (2012). Community- based mangrove management: A review on status and sustainability. J Environ. Manage, 107, 84- 95.

Fensholt, R., Rasmussen, K., Nielsen, T. T., \& Mbow, C. (2009). Evaluation of earth observation based on long-term vegetation trends-Intercomparing NDVI time series trend analysis consistency of Sahel from AVHRR GIMMS, Terra MODIS, and SPOT VGT data. Remote Sensing of Environment, 113(9), 1886-1898. doi: https://doi.org/10.1016/j.rse.2009.04.004.

Field, C., Osborn, J., Hoffman, L., Polsenberg, J., Ackerly, D., Berry, J., \& Mooney, H. (1998). Mangrove biodiversity and ecosystem function. Global Ecology \& Biogeography Letters, 7(1), 3-14. doi: https://doi.org/10.2307/2997693.

Gilman, E. L., Ellison, J., Duke, N. C., \& Field, C. (2008). Threats to mangroves from climate change and adaptation options: a review. Aquatic Botany, 89(2), 237-250. doi: https://doi.org/10.1016/j.aquabot.2007.12.009 
Giri, C. (2016). Observation and monitoring of mangrove forests using remote sensing: Opportunities and challenges. doi: https://doi.org/10.3390/rs8090783.

Giri, C., Ochieng, E., Tieszen, L. L., Zhu, Z., Singh, A., Loveland, T., \& Duke, N. (2011). Status and distribution of mangrove forests of the world using earth observation satellite data. Global Ecology and Biogeography, 20(1), 154-159. doi: https://doi.org/10.1111/j.14668238.2010.00584.x

Giri, C., Zhu, Z., Tieszen, L. L., Singh, A., Gillette, S., \& Kelmelis, J. A. (2008). Mangrove forest distributions and dynamics (1975-2005) of the tsunami-affected region of Asia. Journal of Biogeography, 35(3), 519-528. https://doi.org/10.1111/j.1365-2699.2007.01806.x

Green, E. P., Clark, C. D., Mumby, P. J., Edwards, A. J., \& Ellis, A. C. (1998). Remote sensing techniques for mangrove mapping. International journal of remote sensing, 19(5), 935-956. doi: https://doi.org/10.1080/014311698215801.

Godoy, M. D. P., \& Lacerda, L. D. D. (2015). Mangrove response to climate change: A review of recent findings on mangronve extension and distribution. Annals of the Brazilian Academy of Sciences, 87, 651- 667.

Hai- Hoa, N. (2016). Using landsat imagery and vegetation indices differencing to detect mangrove change: a case in Thai Thuy district, Thai Binh province.

Hai-Hoa, N., McAlpine, C., Pullar, D., Johansen, K., \& Duke, N. C. (2013). The relationship of spatialtemporal changes in fringe mangrove extent and adjacent land-use: a Case study of Kien Giang coast, Vietnam. Ocean \& coastal management, 76, 12-22. doi: https://doi.org/10.1016/j.ocecoaman.2013.01.003.

Hanifah, A., \& Addiwan, A. (2018). Community-based mangrove forest management action in Rangsang region, district of Kepulauan Meranti, Riau. MOJ Ecology and Environmental Sciences, 3, 339- 347.

Hashim, H., Latif, Z. A., \& Adnan, N. A. (2019). Urban vegetation classification with NDVI threshold value method with very high resolution (VHR) Pleiades imagery. The International Archives of the Photogrammetry, Remote Sensing and Spatial Information System. $6^{\text {th }}$ International Conference on Geomatics and Geospatial Technology. Kuala Lumpur, Malaysia.

Hawkins, S., Robertson, S., Thu Thuy, P., Xuan To, P., McNally, R., Van Cuong, C., \& Duc Tu, N. (2010). Roots in the water: legal frameworks for mangrove PES in Vietnam.

Hogarth, P. J. (2015). The biology of mangroves and seagrasses. Oxford University Press. doi: https://doi.org/10.1093/acprof:oso/9780198716549.001.0001

Hong, P. N., \& San, H. T. (1993). Mangroves of Vietnam (Vol 7). IUCN.

Hu, L., Li, W., \& Xu, B. (2018). The role of remote sensing on studying mangrove forest extent change. International Journal of Remote Sensing, 1-23. doi: https://doi.org/10.1080/01431161.2018.1455239.

Hu, Q., Wu, W., Xia, T., Yu, Q., Yang, P., Li, Z., \& Song, Q. (2013). Exploring the use of Google Earth imagery and object-based methods in land use/cover mapping. Remote Sensing, 5(11), 60266042. doi: https://doi.org/10.3390/rs5116026.

Ibrahim, N. A., Mustapha, M. A., Lihan, T., \& Ghaffar, M. A. (2013). Determination of mangrove change in Matang mangrove forest using multi-temporal satellite imageries. AIP. Proc, 1571, 487- 492. https://doi.org/10.1063/1.4858702

Jhaveri, N. J., Petrova, S., Sommerville, M., Van Hue, L. T., \& Ngoc Huy. N. (2017). Red River Delta Coastal Spatial Planning and Mangrove Governance Assessment. Washington, DC: USAID Tenure and Global Climate Change Program.

Kongkeaw, C., Kittitornkool, J., Vandergeest, P., \& Kittiwatanawong, K. (2019). Explaining success in community based mangrove management: four coastal communities along the Andaman Sea, Thailand. Ocean and Coastal Management. doi: https://doi.org/10.1016/j.ocecoaman.2019.104822

Kuenzer, C., Bluemel, A., Gebhardt, S., Quoc, T. V., \& Dech, S. (2011). Remote sensing of mangrove 
ecosystems: A review. Remote Sensing, 3(5), 878-928. https://doi.org/10.3390/rs3050878.

Laengner, M. L., Siteur, K., \& Wal, D. V. D. (2019). Trends in the Seaward extent of saltmarshes across Europe from long term satellite data. Remote Sensing,11. doi: https://doi.org/10.3390/rs11141653

Malarvizhi, K., Kumar, S. V., \& Porchelvan, P. (2016). Use of High-Resolution Google Earth Satellite Imagery in Landuse Map Preparation for Urban Related Applications. Procedia Technology, 24, 1835-1842. doi:https://doi.org/10.1016/j.protcy.2016.05.231.

Maryantika, N., \& Lin C. (2017). Exploring changes of land use and mangrove distribution in the economic area of Sidoarjo district, East Java using multi-temporal Landsat images. Information Processing in Agriculture, 4, 321- 332.

Mas, J. F. (1999). Monitoring land-cover changes a comparison of change detection techniques. International journal of remote sensing, 20(1), 139-152. doi: https://doi.org/10.1080/014311699213659.

Mohammad, N. A., SA, S. M., \& Akhir, J. M. (2017). Land use evaluation for Kuala Selangor, Malaysia using remote sensing and GIS technologies. Geografia-Malaysian Journal of Society and Space, 3(1).

OECD. (2018). Building resilience cities: An assessment of disaster risk management policies in Southeast Asia. OECD Green Growth Studies, OECD Publishing, Paris.

Olofsson, P., Foody, G.M., Herold, M., Stehman, S.V., Woodcock, C.E., \& Wulder, M.A. (2014). Good practices for estimating area and assessing accuracy of land change. Remote Sensing of Environment 148, 42-57.

Primavera, J. H. (1998). Mangroves as nurseries: shrimp populations in mangrove and nonmangrove habitats. Estuarine, Coastal and Shelf Science, 46(3), 457-464. doi: https://doi.org/10.1006/ecss.1997.0275.

Richards, D. R., \& Friess, D. A., (2012). Rate and drivers of mangrove deforestation in Southeast Asia 2002- 2012. Proc. Natl. Acad. Sci, USA, 113, 3344- 3349.

Romañach, S. S., DeAngelis, D. L., Koh, H. L., Li, Y., Teh, S. Y., Barizan, R. S. R., \& Zhai, L. (2018). Conservation and restoration of mangroves: Global status, perspectives, and prognosis. Ocean \& Coastal Management, 154, 72-82. doi: https://doi.org/10.1016/j.ocecoaman.2018.01.009

Rouse, J.W., Haas, R.H., Schell, J.A., \& Deering, D.W (1973). Monitoring vegetation systems in the Great Plains with ERTS. In: Third ERTS Symposium. NASA, pp. 309-317.

Satyanarayana, B., Muslim, A. M., Horsali, N. A. I., Zauki, N. A. M., Otero, V., Nadzri, M. I., \& DahdouhGuebas, F. (2018). Status of the undisturbed mangroves at Brunei Bay, East Malaysia: a preliminary assessment based on remote sensing and ground-truth observations. PeerJ, 6, e4397. doi: https://doi.org/10.7717/peerj.4397

Singh, A. (1989). Review article digital change detection techniques using remotely-sensed data. International journal of remote sensing, 10(6), 989-1003. doi: https://doi.org/10.1080/01431168908903939 .

Spalding, M. (2010). World atlas of mangroves. Routledge. https://doi.org/10.4324/9781849776608

Taufik, A., Ahmad, S. S. S., \& Ahmad, A. (2016). Classification of Landsat 8 satellite data using NDVI thresholds. Journal of Telecommunication, Electronic and Computer Engineering, 8, 37- 40.

Thampanya, U., Vermaat, J. E., Sinsakul, S., \& Panapitukkul, N. (2006). Coastal erosion and mangrove progradation of Southern Thailand. Estuarine, coastal and shelf science, 68(1-2), 75-85. doi: https://doi.org/10.1016/j.ecss.2006.01.011

The Government of Vietnam, MARD (Ministry of Agriculture and Rural Development). (2008). A synthesis report on proposed restoration and development of mangrove forest in coastal zones from 2008-2015.

The Government of Vietnam. (2016a). Decree 119/ 2016/ ND-CP. Policy on Coastal forest management, protection, rehabilitation, and development in response to climate change 
The Government of Vietnam. (2016b). No 1427/QD-UBND. A decision on the approval of forest inventory results of Hai Phong City.

The Government of Vietnam. (2017). Decree 2964/QĐ-UBND on approving the plan for implementation of the sustainable forest development program of Hai Phong City for 20182020.

The Government of Vietnam. (1998). Decision No. 245/1998/QD-TTg on Regulation on State Management of Forest and Forest Land.

The Government of Vietnam. (2001). Decision No. 08/2001/QD-TTg on Management of Natural Forest as Special Use Forest, Protection Forest, and Production Forest.

The Government of Vietnam. (2006). Decision Promulgating the Regulation on Forest Management, No. 186/2006/QD-TTg.

Thomas, M., Lucas, R., Bunting, P., Hardy, A., Rosenqvist, A., \& Simard, M. (2017). Distribution and drivers of global mangrove forest change, 1996- 2010. PLOS ONE, 12. doi: https://doi.org/10.1371/journal.pone.0179302 .

Thomas, N., Bunting, P., Lucas, R., Hardy, A., Rosenqvist, A., \& Fatoyinbo, T. (2018). Mapping mangrove extent and change: A globally applicable approach. Remote Sensing, 10, 1466; doi: https://doi.org/10.3390/rs10091466

Tucker, C. J., Pinzon, J. E., Brown, M. E., Slayback, D. A., Pak, E. W., Mahoney, R.,\& El Saleous, N. (2005). An extended AVHRR 8-km NDVI dataset compatible with MODIS and SPOT vegetation NDVI data. International Journal of Remote Sensing, 26(20), 4485-4498. doi: https://doi.org/10.1080/01431160500168686

Van, T.T., Wilson, N.,Thanh-Tung, H., Quithoudt, K., Quang-Minh, V., Xuan-Tuan, L., DahdouhGuebas, F., \& Koedam, N. (2015). Changes in mangrove vegetation area and character in a war and land use change affected region of Vietnam (Mui Ca Mau) over six decades. Acta Oecologica, 63, 71- 81.

Vietnam Law on Forestry. (2017). Law on Foretry (both Vietnamese and English versions).

Wang, Q., \& Tenhunen, J. D. (2004). Vegetation mapping with multitemporal NDVI in North Eastern China transect (NECT). International Journal of Applied Earth Observation and Geoinformation, 6(1), 17-31. doi: https://doi.org/10.1016/j.jag.2004.07.002

Woodroffe, C. D., Rogers, K., McKee, K. L., Lovelock, C. E., Mendelssohn, I. A., \& Saintilan, N. (2016). Mangrove sedimentation and response to relative sea-level rise. Annual Review of Marine Science, 8, 243-266. doi: https://doi.org/10.1146/annurev-marine-122414-034025.

Yilmaz, O., Mansuroglu, S., \& Yilmaz, R. (2013). SWOT analysis of ecotourism as a tool for sustainable development: A case research in north-west black sea coastal zone of Turkey. J. Environ. Prot. Ecol, 14, 786- 798.

Zhang, Z., Treitz, P., Chen, D., \& Quan, C. (2017), Mapping mangrove forests using multi-tidal remotely- sensed data and a decision- tree based procedure. International Journal of Applied Earth Observation and Geoinformations, 62, 201- 2017. doi: https://doi.org/10.1016/j.jag.2017.06.010 